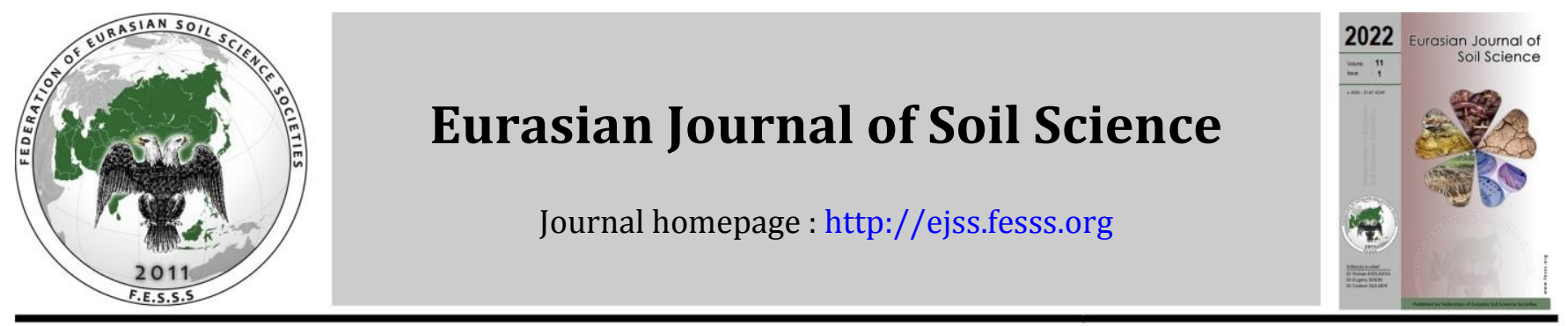

\title{
Yield of sugar beet and changes in phosphorus fractions in relation to long term $P$ fertilization in chestnut soil of Kazakhstan
}

\author{
Gulzhan Zhaksybayeva *, Alimbay Balgabayev, Tursunay Vassilina, \\ Aigerim Shibikeyeva, Almagul Malimbayeva
}

Kazakh National Agrarian Research University, 050010, Almaty, Kazakhstan

\section{Article Info}

Received : 11.02 .2021

Accepted : 02.08.2021

Available online : 08.08.2021

\section{Author(s) \\ G. Zhaksybayeva* \\ A. Balgabayev \\ T. Vassilina \\ A. Shibikeyeva \\ A. Malimbayeva}

* Corresponding author

\begin{abstract}
Excessive phosphorus (P) application can alter soil $\mathrm{P}$ availability and limit plant growth by $\mathrm{P}$ fixation into different organic and inorganic $\mathrm{P}$ forms. However, it remains uncertain whether these changes happen after limited fertilization or an excessive rate applied under the crop rotation. The current study aimed to investigate the yield of sugar beet in response to long term $\mathrm{P}$ fertilization, and to investigate long-term $\mathrm{P}$ fertilization effects on soil $\mathrm{P}$ fractions after long-term fertilizations in chestnut soil of Kazakhstan. A long-term study (56 years) was conducted to assess the changes in total $\mathrm{P}$, available $\mathrm{P}$ and inorganic $\mathrm{P}(\mathrm{Pi})$ fractions in response to different $P$ rates applied to sugar beet. Inorganic $P$ fractions were determined using the Ginzburg and Lebedeva (1971) and Ginzburg (1981) methods. Our findings demonstrated that different P rates significantly increased the total $\mathrm{P}$ and available $\mathrm{P}$ in the inorganic $\mathrm{P}$ fractions compared to $\mathrm{N}_{0} \mathrm{P}_{0} \mathrm{~K}_{0}$ treatment (Absolute control). The $\mathrm{N}_{1} \mathrm{P}_{2} \mathrm{~K}_{1}(100 \%$ of recommended level of NK but $200 \%$ of $\mathrm{P}$ ) treatment had a maximum yield and sugar content of sugar beet. Compared with $\mathrm{N}_{0} \mathrm{P}_{0} \mathrm{~K}_{0}$, the proportions of Ca- $\mathrm{P}_{\mathrm{I}}, \mathrm{Ca}-\mathrm{P}_{\mathrm{II}}, \mathrm{Fe}-\mathrm{P}$ and Al-P of total inorganic $\mathrm{P}$ fractions associated with under fertilizer treatments increased. The highest content of fractioned $\mathrm{P}$ was found in the form of Ca-P $\mathrm{PII}$.
\end{abstract}

Keywords: Sugar beet, chestnut soil, phosphorus, P fertilization, inorganic P fractions.

(C) 2022 Federation of Eurasian Soil Science Societies. All rights reserved

\section{Introduction}

In modern agriculture, maximizing and sustaining crop yields are the main objectives. One of the major problems constraining the development of an economically successful agriculture is nutrient deficiency (Fageria and Baligar, 2005). Phosphorus (P) deficiency is a universal constraint to crop production and constitutes the second most important soil fertility problem throughout the World (Rashid et al., 2005). Phosphorus is an essential nutrient for both plants and animals. It is estimated that some 30 to $50 \%$ of the increase in world food production since the 1950s is attributable to fertilizer use, including P use (Higgs et al., 2000). Phosphorus deficiency in crop plants is a widespread problem in various parts of the world, especially in highly weathered acidic soils (Fageria and Baligar, 1997, 2001; Faye et al., 2006). Worldwide applications of phosphate fertilizers now exceed over 30 million metric tons annually (Epstein and Bloom, 2005). The deficiency of this element is related to several factors. These factors are low natural level in some soils, high immobile or fixation capacity of acidic soils, uptake of modern crop cultivars in large amount, loss by soil erosion, and use of low rate by farmers in developing countries. Biotic stresses such as crop infestation of insects, diseases, and weeds also reduce P use efficiency in crop plants (Fageria, 2009).

Soils contain organic and inorganic phosphorus compounds. Because organic compounds are largely derived from plant residues, microbial cells, and metabolic products, components of soil organic matter are often

https://doi.org/10.18393/ejss.980372

http://ejss.fesss.org/10.18393/ejss. 980372 
similar to these source materials. Approximately $1 \%$ of the organic phosphorus is in the phospholipid fraction; 5 to $10 \%$ is in nucleic acids or degradation products, and up to $60 \%$ is in an inositol polyphosphate fraction. Phospholipids and nucleic acids that enter the soil are degraded rapidly by soil microorganisms (Ko and Hora, 1970; Anderson, 1967). The more stable, and therefore more abundant, constituents of the organic phosphorus fraction are the inositol phosphates. Inositol polyphosphates are usually associated with high-molecular- weight molecules extracted from the soil, suggesting that they are an important component of humus (Omotoso and Wild, 1970).

Soils normally contain a wide range of microorganisms capable of releasing inorganic orthophosphate from organic phosphates of plant and microbial origin (Alexander, 1977). Conditions that favor the activities of these organisms, such as warm temperatures and near-neutral $\mathrm{pH}$ values also favor mineralization of organic phosphorus in soils (Alexander, 1977; Anderson, 1975). The enzymes involved in the cleavage of phosphate from organic substrates are collectively called phosphatases. Microorganisms produce a variety of phosphatases that mineralize organic phosphate (Feder, 1973). Humic acids and other organic acids often reduce phosphorus fixation through the formation of complexes (chelates) with $\mathrm{Fe}, \mathrm{Al}, \mathrm{Ca}$, and other cations that react with phosphorus (Holford and Mattingly, 1975; Hedley et al., 1982; Wang et al., 2010). Studies have shown that organic phosphorus is much more mobile in soils than inorganic sources.

Inorganic phosphorus entering the soil solution, by mineralization or fertilizer additions, is rapidly converted into less available forms. Sorption and precipitation reactions are involved. The sorption of inorganic phosphorus from solution is closely related to the presence of amorphous iron and aluminum oxides and hydrous oxides and the amounts of calcium carbonate $\left(\mathrm{CaCO}_{3}\right)$ (Holford and Mattingly, 1975; Cogger and Duxbury, 1984; Solis and Torrent, 1989; Kizllkaya et al., 2007). Hydrous oxides and oxides of aluminum and iron often occur as coatings on clay mineral surfaces (Williams et al., 1958; Greenland et al., 1968, Shen and Rich, 1962), and these coatings may account for a large portion of the phosphorus sorption associated with the clay fraction of soils. Even in calcareous soils, hydrous oxides have been demonstrated as being important in phosphorus sorption, as was demonstrated by Shukla et al. (1971) for calcareous lake sediments, Holford and Mattingly (1975) for calcareous mineral soils, and Porter and Sanchez (1992) for calcareous Histosols. In calcareous soils, phosphorus (or phosphate) sorption to $\mathrm{CaCO} 3$ may be of equal or greater importance than sorption to aluminum and iron oxides (Porter and Sanchez, 1992). In a laboratory investigation with pure calcite, Cole et al (1953) concluded that the reaction of phosphorus with CaCO3 consisted of initial sorption reactions followed by precipitation with increasing concentrations of phosphorus. Phosphorus sorption may occur in part as a multilayer phenomenon on specific sites of the calcite surface (Holford and Mattingly, 1975, Griffin and Jurinak, 1973). As sorption proceeds, lateral interactions occur between sorbed phosphorus, eventually resulting in clusters. These clusters in turn serve as centers for the heterogeneous nucleation of calcium phosphate crystallites on the calcite surface.

Crop yields are often limited by low $\mathrm{P}$ availability in soils, owing mainly to adsorption and precipitation reactions of both indigenous soil $\mathrm{P}$ and applied fertilizer $\mathrm{P}$ with iron (Fe), aluminum (Al), or calcium (Ca) (Khiari and Parent, 2005). Low P uptake efficiency of plants is associated primarily with limited P availability in native soil. Consequently, large amounts of expensive inorganic $P$ fertilizers need to be applied to many agricultural soils to attain reasonable crop yields (Ayaga et al., 2006).

Soil inorganic $\mathrm{P}(\mathrm{Pi})$ represents the dominant component in the soil $\mathrm{P}$ pool, accounting for about $75-85 \%$ of soil total P. Soil Pi is represented as various fractions such as Ca-P, Fe-P, Al-P and O-P (P occluded within Fe oxides) (Solis and Torrent, 1989; Kızılkaya et al., 2007). However, in calcareous soils, most Pi is present in various Ca-bound forms and there are great differences in $\mathrm{P}$ availability among these Ca-P fractions (Yang and Jacobsen, 1990). A few studies have assessed fractionated $P$ and available $P$ in soils on a regional or country scale in chestnut soil of Kazakhstan. Chestnut soils a soil type occurring in arid steppes. The soils cover large areas of Turkey, Mongolia, northern China, the United States, and Kazakhstan (Saparov, 2014; Yertayeva et al., 2018; 2019; Suleimenova et al., 2019). The climate in the chestnut soil zone is continental and arid. The genetic and zonal properties of chestnut soils include deficient drainage, a shortage of productive moisture, alkalinity, and soil heterogeneity. The parent material consists chiefly of calcareous deposits with a predominance of loess like loams, calcareous sandy loams, calcareous sands, sandy loams, and alluvium. Chestnut soils contain carbonates and, in most cases, gypsum in the lower part of the profile. The presence of readily soluble salts causes the alkalinity of chestnut soils.

The objectives of the present study were (i) to investigate the yield of sugar beet in response to long term $\mathrm{P}$ fertilization, and (ii) to investigate long-term $\mathrm{P}$ fertilization effects on soil $\mathrm{P}$ fractions after long-term fertilizations in chestnut soil of Kazakhstan. 


\section{Material and Methods}

\section{Site Description}

The long-term field experiment was located on the experimental station of the Kazakh Research Institute of Agriculture and Plant Growing, Almaty, Kazakhstan (4309'32.8"N 76²6'57.3"E). Sugar beet (Beta vulgaris L.) is the major crop in this region, which are generally planted in May and harvested in October. The experiment was established to study the effect of different fertilizer treatments and crop rotations on yield of sugar beet and soil phosphorus fractions. The year the experiment was established was 1962. The locations of the experimental site were characterized by the continental climate (large daily and annual fluctuations in air temperature, characterized by cold winters and long hot summers). The annual mean precipitation and mean temperature from the establishment of the experiment is shown in Figure 1.

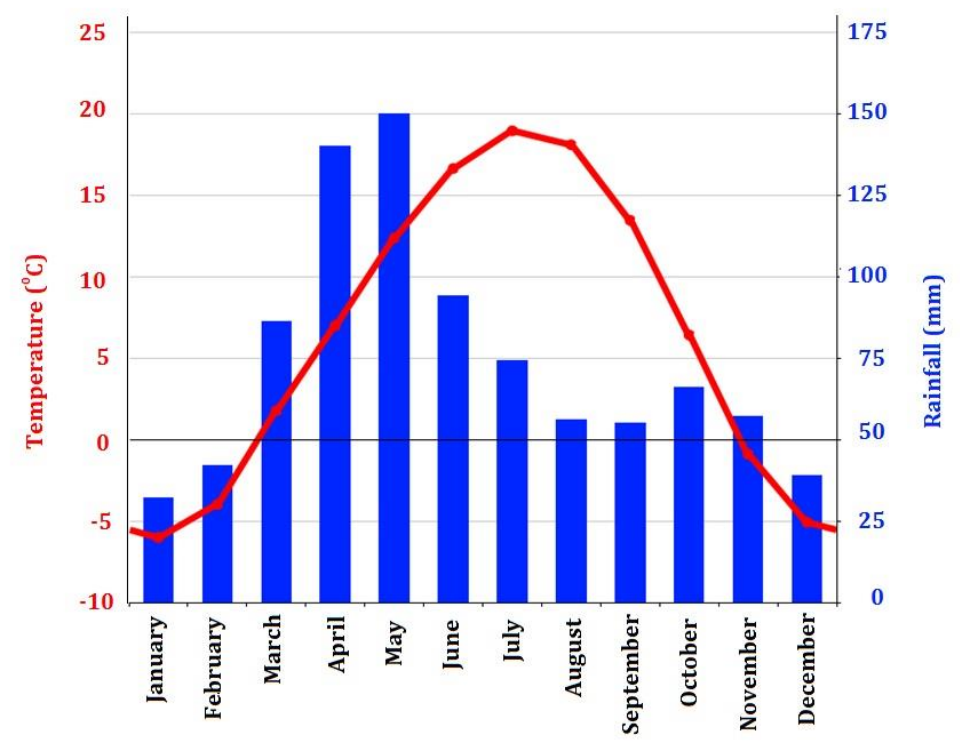

Figure 1. Monthly average temperature $\left({ }^{\circ} \mathrm{C}\right)$ and distribution of precipitation $(\mathrm{mm})$ of the experimental area.

The standard climatological long-term average (1961-2020) precipitation and temperature was $863 \mathrm{~mm}$ and $6.8 \circ \mathrm{C}$, respectively. The altitude of the trial site is $700 \mathrm{~m}$. The soil belongs to the general soil type of dark chestnut. The $\mathrm{pH}$ was 8.61-8.62 (alkaline reaction), soil organic matter content was $2.27-2.30 \%$ (moderate). Total $\mathrm{N}$ was $0.171-0.182 \%$, total phosphorus was $0.20-0.21 \%$ and total potassium was $1.62-1.75 \%$. Available nitrogen, phosphorus and potassium contents were $23.1-24.8 \mathrm{mg} / \mathrm{kg}, 20.2-27.0 \mathrm{mg} / \mathrm{kg}$ and $424-455 \mathrm{mg} / \mathrm{kg}$, respectively.

\section{Experimental Design Description}

A long term experiment was established at the experimental station of the Kazakh Research Institute of Agriculture and Plant Growing in May 2018. Twelve experimental plots of $216 \mathrm{~m}^{2}$ area $(11.2 \mathrm{~m} \times 19.3 \mathrm{~m})$ separated by $0.7 \mathrm{~m}$ cement barriers were set in completely randomized block design with five treatments and four replications. The crop rotation in these fields was equal, consisting of alfalfa + winter wheat, alfalfa, and alfalfa, sugar beet, winter wheat, sugar beet, corn. The sources of fertilizers used were urea $46 \% \mathrm{~N}$, double superphosphate $47 \% \mathrm{P}_{2} \mathrm{O}_{5}$ and potassium chloride $60 \% \mathrm{~K}_{2} \mathrm{O}$. The doses of mineral $\mathrm{N}$, $\mathrm{P}$, and $\mathrm{K}$ are shown in Table 1.

Table 1. Doses of applied N, P, and K in the field experiment

\begin{tabular}{|c|c|c|c|c|c|c|}
\hline \multirow{2}{*}{$\begin{array}{l}\text { Fertilizer } \\
\text { treatments }\end{array}$} & \multicolumn{3}{|c|}{ In 2018} & \multicolumn{3}{|c|}{ Totally (from 1962 to 2018 ) } \\
\hline & $\mathrm{N}\left(\mathrm{kg} \mathrm{ha}^{-1}\right)$ & $\mathrm{P}\left(\mathrm{kg} \mathrm{ha}^{-1}\right)$ & $\mathrm{K}\left(\mathrm{kg} \mathrm{ha}^{-1}\right)$ & $\mathrm{N}\left(\mathrm{kg} \mathrm{ha}^{-1}\right)$ & $\mathrm{P}\left(\mathrm{kg} \mathrm{ha}^{-1}\right)$ & $\mathrm{K}\left(\mathrm{kg} \mathrm{ha}^{-1}\right)$ \\
\hline $\mathrm{N}_{0} \mathrm{P}_{0} \mathrm{~K}_{0}$ & 0 & 0 & 0 & 0 & 0 & 0 \\
\hline $\mathrm{N}_{1} \mathrm{P}_{0} \mathrm{~K}_{1}$ & 100 & 0 & 60 & 5600 & 0 & 3360 \\
\hline $\mathrm{N}_{1} \mathrm{P}_{1} \mathrm{~K}_{1}$ & 100 & 90 & 60 & 5600 & 3360 & 3360 \\
\hline $\mathrm{N}_{1} \mathrm{P}_{1.5} \mathrm{~K}_{1}$ & 100 & 135 & 60 & 5600 & 5040 & 3360 \\
\hline $\mathrm{N}_{1} \mathrm{P}_{2} \mathrm{~K}_{1}$ & 100 & 180 & 60 & 5600 & 6720 & 3360 \\
\hline
\end{tabular}

$\mathrm{N}_{0} \mathrm{P}_{0} \mathrm{~K}_{0}=$ Absolute control (no applied fertilizers)

$\mathrm{N}_{1} \mathrm{P}_{0} \mathrm{~K}_{1}=$ Phosphorus control, $100 \%$ of recommended level of NK

$\mathrm{N}_{1} \mathrm{P}_{1} \mathrm{~K}_{1}=100 \%$ of recommended level of NPK

$\mathrm{N}_{1} \mathrm{P}_{1.5} \mathrm{~K}_{1}=100 \%$ of recommended level of NK but $150 \%$ of $\mathrm{P}$

$\mathrm{N}_{1} \mathrm{P}_{2} \mathrm{~K}_{1}=100 \%$ of recommended level of $\mathrm{NK}$ but $200 \%$ of $\mathrm{P}$ 
Sugar beets were grown after winter wheat, and their nourishment consisted exclusively of mineral fertilization according to the above variants. The row spacing was $45 \mathrm{~cm} \times 17 \mathrm{~cm}$. Theoretically, the plant density was 130 thousand plants per ha-1. In the spring, prior to sowing beet seeds, Mineral $\mathrm{P}$ and $\mathrm{K}$ fertilizers were applied in autumn and were incorporated into the soil by moderate deep tillage $(0.2 \mathrm{~m})$. Mineral $\mathrm{N}$ was applied in the spring, before the beet planting, applied in a topdressing treatment during the sugar beet growth phase of 6 leaves, according to the experiment design. The surface area of the experimental plots was $28 \mathrm{~m}^{2}$, of which $21.6 \mathrm{~m}^{2}$ was harvested in October. At harvest (205 days after sowing), plants of each plot were harvest to determine roots yield (ton ha-1). Sugar Content Analyses (expressed as \%) was estimated in fresh samples of sugar beet root by using Saccharometer/Polarimeter with SU-4 model.

Soil Sampling: The soil samples were collected at two depths: 0-20 cm and 20-40 cm. Soil samples were processed in the laboratory by removing and visible plant residues and Stones larger than $2 \mathrm{~mm}$ immediately after sampling. Soil samplings were then air-dried.

Soil sample analyses: The air dried soil samples were ground to pass through a $2 \mathrm{~mm}$ sieve for laboratory analysis. Soil samples were digested in a tri-acid mixture $\left(\mathrm{HNO}_{3}, \mathrm{HClO}_{4}\right.$, and $\mathrm{H}_{2} \mathrm{SO}_{4}$ at a 3:1:1 ratio) for determining total phosphorus (Total P). The P concentration in the digest was determined colorimetrically using the vanadomolybdate method. Soil organic phosphorus (Po) was determined by combustion at $550^{\circ} \mathrm{C}$ and extraction with $4 \mathrm{M} \mathrm{H}_{2} \mathrm{SO}_{4}$. Machigan method was used to determine available $\mathrm{P}$ using the colorimetric method after the extraction with $1 \%\left(\mathrm{NH}_{4}\right)_{2} \mathrm{CO}_{3}$ (GOST 26205-91)

Soil inorganic $P$ fraction: Inorganic $\mathrm{P}(\mathrm{Pi})$ fractions were measured according to a fractionation scheme of Ginzburg and Lebedeva (1971) and Ginzburg (1981). Briefly, the fractionation involved a sequential extraction with (i) $1 \%\left(\mathrm{NH}_{4}\right)_{2} \mathrm{SO}_{4}+0.25 \%\left(\mathrm{NH}_{4}\right)_{2} \mathrm{MoO}_{4}(\mathrm{pH}=4.8)$ to extract $\mathrm{Ca}-\mathrm{P}_{\mathrm{I}}$, (ii) $\mathrm{CH}_{3} \mathrm{COONH}_{4}+\mathrm{CH}_{3} \mathrm{COOH}$ $+0.25 \%\left(\mathrm{NH}_{4}\right)_{2} \mathrm{MoO}_{4}(\mathrm{pH}=4.3)$ to extract Ca-P II, (iii) $0.5 \mathrm{~N} \mathrm{NH}_{4} \mathrm{~F}+0.1 \mathrm{~N} \mathrm{NaOH}+0.5 \mathrm{~N} \mathrm{H}_{2} \mathrm{SO}_{4}$ to obtain Al-P, (iv) $0.5 \mathrm{~N} \mathrm{NH}_{4} \mathrm{~F}+0.1 \mathrm{~N} \mathrm{NaOH}+0.5 \mathrm{~N} \mathrm{H}_{2} \mathrm{SO}_{4}$ to obtain Fe-P, (v) $0.5 \mathrm{~N} \mathrm{NH}_{4} \mathrm{~F}+0.1 \mathrm{~N} \mathrm{NaOH}+0.5 \mathrm{~N} \mathrm{H}_{2} \mathrm{SO}_{4}$ to extract Ca-PIII.

\section{Results and Discussion}

\section{Yield and sugar content of sugar beet}

Effect of long term P fertilization on yield and sugar content of sugar beet was evaluated (Figure 2). Application of all fertilization significantly influenced the sugar beet yield and sugar content compared to untreated (control) plants (Figure 2). On average, plants grown on the absolute control plot $\left(\mathrm{N}_{0} \mathrm{P}_{0} \mathrm{~K}_{0}\right)$ yielded the lowest, but at the same level, as those fertilized $100 \%$ of recommended level of $\mathrm{NK}+150 \%$ of $\mathrm{P}$ $\left(\mathrm{N}_{1} \mathrm{P}_{1.5} \mathrm{~K}_{1}\right)$ and $100 \%$ of recommended level of $\mathrm{NK}$ but $200 \%$ of $\mathrm{P}\left(\mathrm{N}_{1} \mathrm{P}_{2} \mathrm{~K}_{1}\right)$. This is the indicator that $\mathrm{P}$ was the most limiting yield forming nutrient. Yield of sugar beet in-growth in chestnut soil showed high differences, related to $\mathrm{P}$ rates. The highest yield increase of $98.7 \%$ was noted for the treatment $\mathrm{N}_{1} \mathrm{P}_{1.5} \mathrm{~K}_{1}$. Similar results were obtained by Gunarto et al. (1985) and Yousaf et al. (1999) on several vegetable crops. Numerous studies have reported that inorganic NPK fertilizer increased growth in some species by enhancing nitrogen, phosphorus and potassium uptake (Gülser et al., 2019). In the light of above presented facts, the key problem concerns yield forming functions of P. Effect of tested fertilizing treatments were variable, depending on the P doses. This is in agreement with study other studies (Barlog et al., 2013). In 2018, beet yield increased along the increasing degree of $\mathrm{P}$ balancing. The highest yield produced crop grown in the treatment $\mathrm{N}_{1} \mathrm{P}_{1.5} \mathrm{~K}_{1}$ (Figure 2). Our results corroborate earlier studies about the positive response of sugar beet to NPK fertilizers to exploit its yielding potential (Barłóg et al., 2010, 2013).

\section{Total $P$ and available $P$}

Long term $P$ fertilization significantly increased total $P$ and available $P$ concentrations within 0-20 and 20-40 $\mathrm{cm}$ soil depth (Figure 3a,b). Compared to $\mathrm{N}_{0} \mathrm{P}_{0} \mathrm{~K}_{0}$ (Absolute control), total $\mathrm{P}$ concentration in the $0-20 \mathrm{~cm}$ soil depth was increased by $4.96 \%, 12.77 \%, 24.64 \%$ and $20.22 \%$ in $\mathrm{N}_{1} \mathrm{P}_{0} \mathrm{~K}_{1}, \mathrm{~N}_{1} \mathrm{P}_{1} \mathrm{~K}_{1}, \mathrm{~N}_{1} \mathrm{P}_{1.5} \mathrm{~K}_{1}$ and $\mathrm{N}_{1} \mathrm{P}_{2} \mathrm{~K}_{1}$, respectively, while available $\mathrm{P}$ concentration was increased by $14.49 \%, 136.71 \%, 148.33 \%$ and $185.02 \%$ in in $\mathrm{N}_{1} \mathrm{P}_{0} \mathrm{~K}_{1}, \mathrm{~N}_{1} \mathrm{P}_{1} \mathrm{~K}_{1}, \mathrm{~N}_{1} \mathrm{P}_{1.5} \mathrm{~K}_{1}$ and $\mathrm{N}_{1} \mathrm{P}_{2} \mathrm{~K}_{1}$, respectively. Phosphorus was accumulated in the $0-20 \mathrm{~cm}$ soil depth in all fertilizer treatments. The majority of $\mathrm{P}$ accumulated in the $0-20 \mathrm{~cm}$ soil depth under $\mathrm{N}_{1} \mathrm{P}_{1.5} \mathrm{~K}_{1}$ treatment. The highest increase in available $\mathrm{P}$ concentration in $\mathrm{N}_{1} \mathrm{P}_{2} \mathrm{~K}_{1}$ treatment observed in the $0-20 \mathrm{~cm}$ soil depth, with the increase of $145.92 \%$ in $20-40 \mathrm{~cm}$ soil depth over $\mathrm{N}_{1} \mathrm{P}_{2} \mathrm{~K}_{1}$ treatment. 

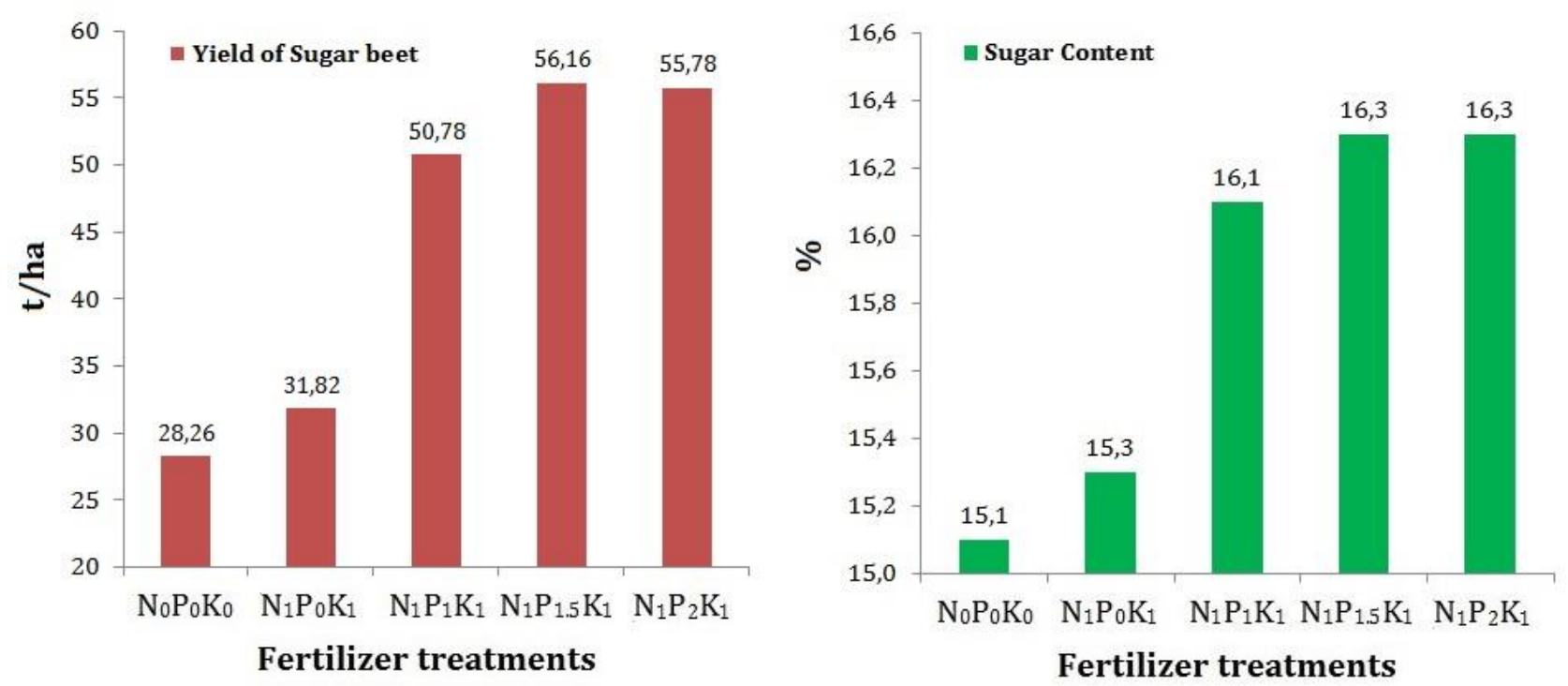

Figure 2. Effect of long term P fertilization on yield and sugar content of sugar beet

Continuous or long term P fertilization significantly increases P accumulation in soils (Ahmed et al., 2019, 2020). Long-term $P$ fertilization causes a prominent increase in different inorganic P (Pi) forms, including available $\mathrm{P}$ fraction (Meason et al., 2009). The results of the present study revealed that long-term $\mathrm{P}$ fertilizer application effects the soil $\mathrm{P}$ directly in loess soils. Compared with the $\mathrm{N}_{0} \mathrm{P}_{0} \mathrm{~K}_{0}$ treatment, NPK treatments significantly increased the accumulation of total $\mathrm{P}$ in the soil (Figure 3a). Previous studies have examined the possibility of increasing the available $\mathrm{P}$ and total $\mathrm{P}$ after long-term $\mathrm{P}$ fertilization (Mao et al., 2015). In this study, the total and available $\mathrm{P}$ content was maximized in the $\mathrm{N}_{1} \mathrm{P}_{2} \mathrm{~K}_{1}$ treatment compared to the $\mathrm{N}_{0} \mathrm{P}_{0} \mathrm{~K}_{0}$ treatment. Zhang et al. (2003) found that the soil content of available Pi that ranged between 5 and $10 \mathrm{mg} \mathrm{kg}^{-1}$ would be enough for plants, whereas a concentration $<5 \mathrm{mg} \mathrm{kg}^{-1}$ would cause P-deficiency. In another study, Bravo et al. (2006) reported that the available concentration of P should be above the critical 6 or $7 \mathrm{mg} \mathrm{kg}^{-1}$ level for optimal cultivation growth. In our findings, NPK application treatments showed a significant increase in total $\mathrm{P}$ and available $\mathrm{P}$ content compared to the treatment of $\mathrm{N}_{0} \mathrm{P}_{0} \mathrm{~K}_{0}$, thus demonstrating interactive effects on the soil concentrations of available P under the application of NPK fertilizers. The longterm effects of the NPK application could be associated with the continuous addition of different rates of inorganic $\mathrm{P}$ in a balanced quantity, which induced the available $\mathrm{P}$ and avoided high fixation of different $\mathrm{P}$ forms (Hinsinger, 2001; Laboski et al., 2004).

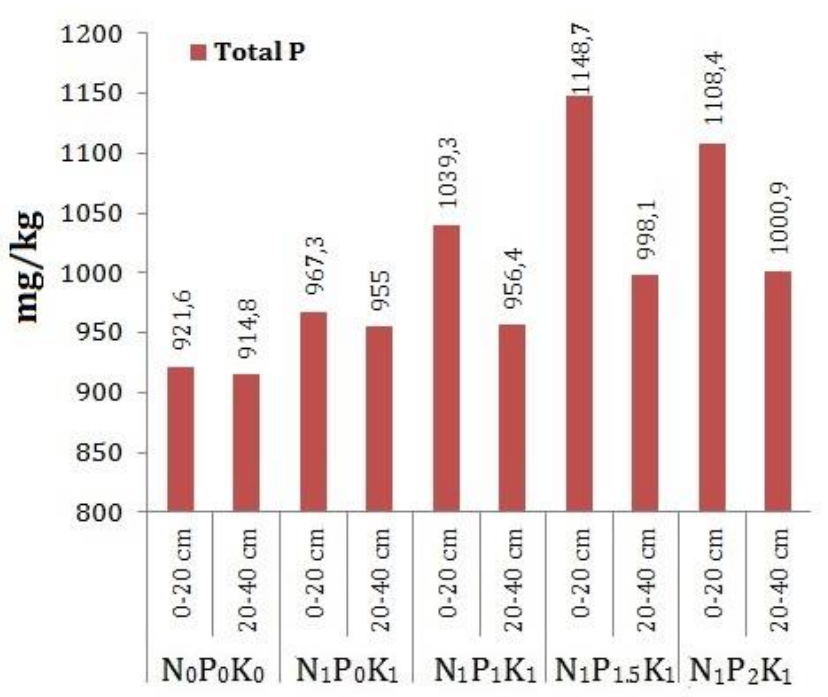

Fertilizer treatments

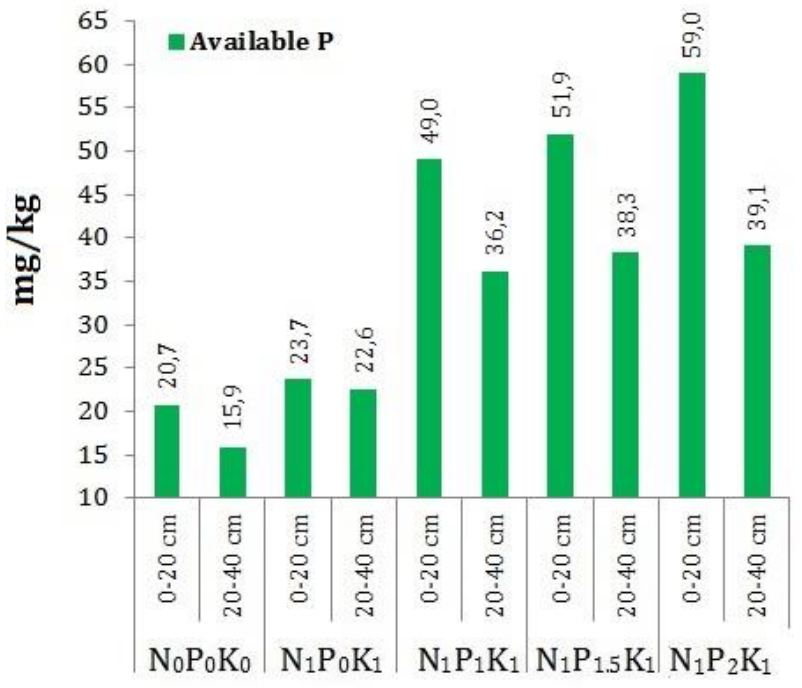

Fertilizer treatments

Figure 3. Effect of long term P fertilization on total P (a) and available P (b) concentrations 


\section{$P$ fractions}

Organic $\mathrm{P}$ proportion in total $\mathrm{P}$ decreased with the increase of $\mathrm{P}$ concentration of fertilizer regardless of treatments, while inorganic $P$ proportion in total $P$ increased under all fertilizer treatments in the $0-20 \mathrm{~cm}$ and 20-40 cm soil depth (Figure 4a). The concentrations of inorganic P fractions (Pi) increased significantly in the 0-20 and 20-40 cm soil depth (Figure 4b). Compared with $\mathrm{N}_{0} \mathrm{P}_{0} \mathrm{~K}_{0}$ (Absolute control), the proportions of Po fractions of the total $P$ associated with $\mathrm{N}_{1} \mathrm{P}_{0} \mathrm{~K}_{1}, \mathrm{~N}_{1} \mathrm{P}_{1} \mathrm{~K}_{1}, \mathrm{~N}_{1} \mathrm{P}_{1.5} \mathrm{~K}_{1}$ and $\mathrm{N}_{1} \mathrm{P}_{2} \mathrm{~K}_{1}$ treatments decreased, while the of proportions of Ca- $\mathrm{P}_{\mathrm{I}}, \mathrm{Ca}-\mathrm{P}_{\mathrm{II}}, \mathrm{Fe}-\mathrm{P}$ and $\mathrm{Al}-\mathrm{P}$ of total inorganic $\mathrm{P}$ fractions associated with under fertilizer treatments increased. Five fractions of $\mathrm{P}$ were quantified from different treatments: $\mathrm{Ca}-\mathrm{P}_{\mathrm{I}}, \mathrm{Ca}-\mathrm{P}_{\mathrm{II}}, \mathrm{Al}-\mathrm{P}, \mathrm{Fe}-\mathrm{P}$,

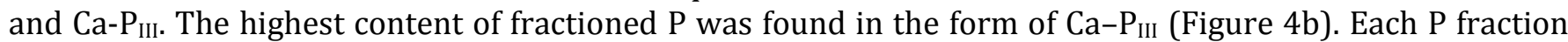
was highest under the $\mathrm{N}_{1} \mathrm{P}_{2} \mathrm{~K}_{1}$ treatment and the lowest under the $\mathrm{N}_{0} \mathrm{P}_{0} \mathrm{~K}_{0}$ (Absolute control) treatment. Among the five long-term treatments, where NPK fertilizers were applied for 56 years along with treatments, Pi fractions followed the trend $\mathrm{Ca}-\mathrm{P}_{\mathrm{III}}>\mathrm{Ca}-\mathrm{P}_{\mathrm{II}}>\mathrm{Fe}-\mathrm{P}>\mathrm{Al}-\mathrm{P}>\mathrm{Ca}-\mathrm{P}_{\mathrm{I}}$. These results are in line with the study findings of Dobermann et al. (2002), who found that the application of P fertilizer increases inorganic P fractions.
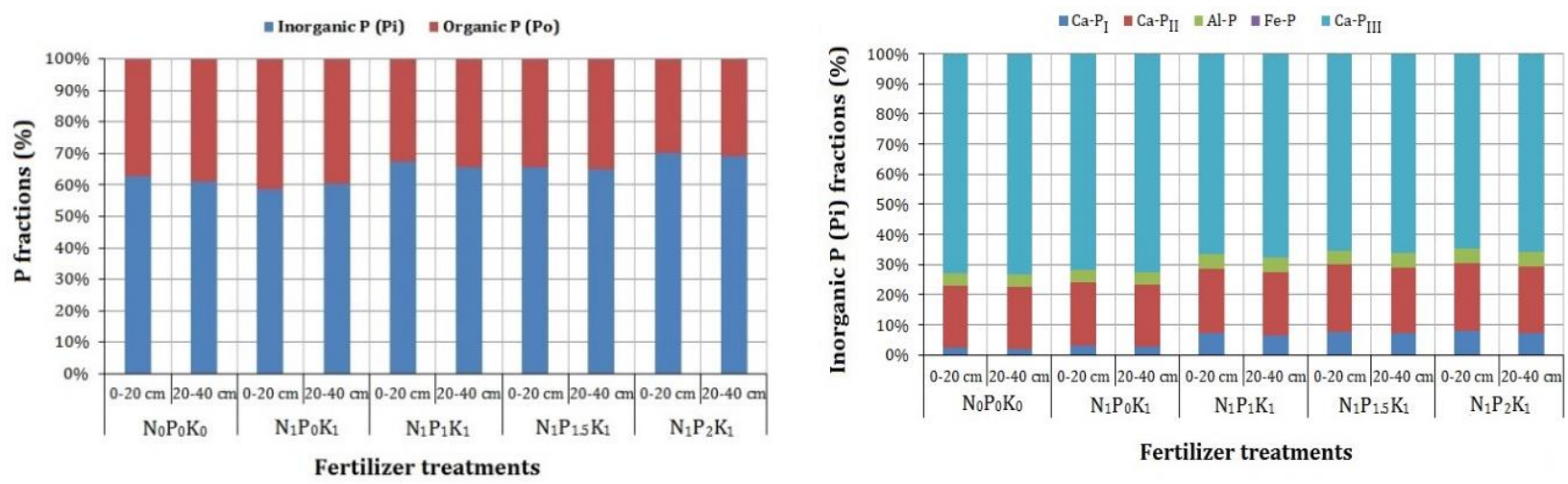

Figure 4. Effect of long term P fertilization on P fractions (a) and inorganic P fractions (b)

\section{Conclusion}

In this study, we compared the responses of soil P fractions and sugar beet yields to different rates of NPK fertilizer added to a sugar beet in a long-term field experiment. The total $\mathrm{P}$ and available $\mathrm{P}$ increased significantly due to the application of different rates of NPK compared with the $\mathrm{N}_{0} \mathrm{P}_{0} \mathrm{~K}_{0}$ (Absolute control) treatment. Long-term NPK fertilization with different level of P influenced the content of all forms of P as determined by a modified Ginzburg and Lebedeva (1971) and Ginzburg (1981) method. The 56 years long fertilization period did not affect the content of organic P in chesnut soils. On the contrary, the results obtained by the Ginzburg methods showed that the contents of Pi (Ca-P, Fe-P and Al-P) fractions were increased. Fertilization considerably increased the content of available $\mathrm{P}$, especially of $\mathrm{P}$ bound to $\mathrm{Ca}$. Application of higher amounts of P-fertilizer resulted in the dominance of the Ca-P fraction in the studied soil. The application of NPK fertilizer on the soil produced a significant increase in the available phosphorus.

\section{Acknowledgements}

The study was carried out with the financial support of the Ministry of Education and Science of the Republic of Kazakhstan (Project No: AP05133193)

\section{References}

Ahmed, W., Jing, H., Kaillou, L., Qaswar, M., Khan. M.N., Jin, C., Geng, S., Qinghai, H., Yiren,L., Guangrong, L., Mei,S., Chao,L., Dongchu,L., Ali,S., Normatov, Y., Mehmood, S., Zhang, H., 2019. Changes in phosphorus fractions associated with soil chemical properties under long-term organic and inorganic fertilization in paddy soils of southern China. PLoS ONE 14(5): e0216881.

Ahmed, W., Qaswar, M., Jing, H., Wenjun, D., Geng, S., Kailou, L., Ying, M., Ao, T., Mei, S., Chao, L., Yongmei, X., Ali, S., Normatov, Y., Mehmood, S., Khan, M.N., Huimin, Z., 2020. Tillage practices improve rice yield and soil phosphorus fractions in two typical paddy soils. Journal of Soils and Sediments 20: 850-861.

Alexander. M., 1977. Introduction to Soil Microbiology. Wiley, New York, USA. 467p.

Anderson. G., 1967. Nucleic acids, derivatives, and organic phosphorus. In: Soil Biochemistry. McLaren, A.D., Peterson, G.H. (Eds.). Vol. 1. Marcel Dekker, New York, USA. pp.67-90.

Anderson. G., 1975. Other organic phosphorus compounds. In: Soil Components. Gieseking, J.E. (Ed.). Sprinter-Verlag, Berlin. pp 305-331. 
Ayaga, G., Todd, A., Brookes, P.C., 2006. Enhanced biological cycling of phosphorus increases its availability to crops in low-input sub-Saharan farming systems, Soil Biology and Biochemistry 38: 81-90.

Barłóg, P., Grzebisz, W., Feć, M., Łukowiak, R., Szczepaniak, W., 2010. Row method of sugar beet (Beta vulgaris L.) with multicomponent fertilizer based on urea-ammonium nitrate solution as a way to increase nutrient use efficiency. Journal of Central European Agriculture 11: 225-234.

Barlog, P., Grzebisz, W., Peplinski, K., Szczepaniak, W., 2013. Sugar beet response to balanced nitrogen fertilization with phosphorus and potassium. Part I. Dynamics of beet yield development. Bulgarian Journal of Agricultural Science 19(6): 1311-1318

Bravo, C., Torrent, J., Giráldez, J.V., González, P., Ordóñez, R., 2006. Long-term effect of tillage on phosphorus forms and sorption in a Vertisol of southern Spain. European Journal of Agronomy 25: 264-269.

Cogger, C., Duxbury, J.M., 1984. Factors affecting phosphorus losses from cultivated organic soils. Journal of Environmental Quality 13: 111-114.

Cole, C.V., Olsen, S.R., Scott, C.O., 1953. The nature of phosphate sorption by calcium carbonate. Soil Science Society of America Journal 17: 352-356.

Dobermann, A., George, T., Thevs, N., 2002. Phosphorus fertilizer effects on soil phosphorus pools in acid upland soils. Soil Science Society of America Journal 66: 652-660.

Epstein, E., Bloom, A.J., 2005. Mineral nutrition of plants: Principles and perspectives. Sunderland, Massachusetts: Sinauer Associates, Inc. Publishers. 412p.

Fageria, N.K., 2009. The use of nutrients in crop plants. CRC Press. New York, USA. 430p.

Fageria, N.K., Baligar, V.C., 2005. Nutrient availability. In: Encyclopedia of soils in the environment. Hillel, D. (Ed.). Elsevier. San Diego, USA. pp. 63-71.

Fageria, N.K., Baligar, V.C., 1997. Response of common bean, upland rice, corn, wheat, and soybean to fertility of an Oxisol. Journal of Plant Nutrition 20: 1279-1289.

Fageria, N.K., Baligar, V.C., 2001. Improving nutrient use efficiency of annual crops in Brazilian acid soils for sustainable crop production. Communications in Soil Science and Plant Analysis 32: 1303-1319.

Faye, I., Diouf, O., Guissé, A., Sène, M., Diallo, N. 2006. Characterizing root responses to low phosphorus in pearl millet [Pennisetum glaucum (L.) R. Br.]. Agronmy Journal 98:1187-1194.

Feder, J., 1973. The phosphatases. In: Environmental Phosphorus Handbook. Griffith, E.J. Beeton, A. Spencer, J.M. Mitchell, D.T., (Eds). John Wiley \& Sons. New York, USA. pp. 475-508.

Ginzburg, K.E., 1981. Phosphorus in the of the USSR. Nauka, Moscow. 242p. [in Russian].

Ginzburg, K.E., Lebedeva, L.S., 1971. Determination of mineral phosphorus compounds in soils. Agrohimiya 1: 25-34. [in Russian].

GOST 26205-91. Soils. Determination of mobile compounds of phosphorus and potassium by Machigin method modified by CINAO. Available at [Access date: 11.02.2021]: https://gostexpert.ru/gost/getDoc/38501

Greenland, D.J., Oades, J.M., Sherwin. T.W., 1968. Electron-microscope observations of iron oxides in some red soils. European Journal of Soil Science 19: 123-126.

Griffin, R.A. Jurinak, J.J., 1973. The interaction of phosphate with calcite. Soil Science Society of America Journal 37: 847850.

Gunarto, L., Yahya, M., Supadmo, H., Buntan, A., 1985. Response of corn to NPK fertilization grown in a Latosol in South Sulawesi, Indonesia. Communications in Soil Science and Plant Analysis 16(11): 1179-1188.

Gülser, C., Zharlygasov, Z., Kızllkaya, R., Kalimov, N., Akça, I., Zharlygasov, Z., 2019. The effect of NPK foliar fertilization on yield and macronutrient content of grain in wheat under Kostanai-Kazakhstan conditions. Eurasian Journal of Soil Science 8(3): 275-281.

Hedley, M.J., Stewart, J.W.B., Chauhan, B.S., 1982. Changes in inorganic and organic soil phosphorus fractions induced by cultivation practices and by laboratory incubations. Soil Science Society of America Journal 46: 970-976.

Higgs, B., Johnston, A.E., Salter, J.L., Dawson, C.J., 2000. Some aspects of achieving sustainable phosphorus use in agriculture. Journal of Environmental Quality 29:80-87.

Hinsinger, P., 2001. Bioavailability of soil inorganic P in the rhizosphere as a_ected by root-induced chemical changes: A review. Plant and Soil 237: 173-195.

Holford, I.C.R., Mattingly, G.E.G., 1975. Phosphate sorption by jurassic oolitic limestones. Geoderma 13: 257-264.

Khiari, L., Parent, L.E., 2005. Phosphorus transformations in acid light-textured soils treated with dry swine manure, Canadian Journal of Soil Science 85: 75-87.

Kızılkaya, R., Bayraklı, F., Sürücü, A., 2007. Relationships between phosphatase activity and phosphorus fractions in agricultural soils. International Journal of Soil Science 2(2): 107-118.

Ko, W.H., Hora, F.K., 1970. Production of phospholipases by soil microorganisms. Soil Science 10: 355-358.

Laboski, C.A.M., Lamb, J.A., 2004. Impact of manure application on soil phosphorus sorption characteristics and subsequent water quality implications. Soil Science 169: 440-448.

Mao, X., Xu, X., Lu, K., Gielen, G., Luo, J., He, L., Donnison, A., Xu, Z., Xu, J., Yang, W., Song, Z., Wang, H., 2015. Effect of 17 years of organic and inorganic fertilizer applications on soil phosphorus dynamics in a rice-wheat rotation cropping system in eastern China. Journal of Soils and Sediments 15: 1889-1899.

Meason, D.F., Idol, T.W., Friday, J.B., Scowcroft, P.G., 2009. Effects of fertilisation on phosphorus pools in the volcanic soil of a managed tropical forest. Forest Ecology and Management 258: 2199-2206. 
Omotoso, T.I., Wild, A., 1970. Content of inositol phosphates in some English and Nigerian soils. European Journal of Soil Science 21: 216-223.

Porter, P.S., Sanchez. C.A., 1992. The effect of soil properties on phosphorus sorption by Everglades Histosols. Soil Science 154: 387-398.

Rashid, A., Awan, Z.I., Ryan, J., 2005. Diagnosing phosphorus deficiency in spring wheat by plant analysis: proposed critical concentration ranges. Communications in Soil Science and Plant Analysis 36: 609-622.

Saparov, A., 2014. Soil Resources of the Republic of Kazakhstan: Current Status, Problems and Solutions. In: Novel Measurement and Assessment Tools for Monitoring and Management of Land and Water Resources in Agricultural Landscapes of Central Asia. Mueller, L., Saparov, A., Lischeid, G. (Eds.). Environmental Science and Engineering. Springer, Cham. pp. 61-73.

Shen, M.J., Rich. C.I., 1962. Aluminum fixation in montmorillonite. Soil Science Society of America Journal 26: 33-36,

Shukla, S.S., Syers J.K., Williams, J.D.H., Armstrong, D.E., Harris. R.F., 1971. Sorption of inorganic phosphate by lake sediments. Soil Science Society of America Journal 35: 244-249.

Solis, P., Torrent, J., 1989. Phosphate fractions in calcareous Vertisols and Inceptisols of Spain. Soil Science Society of America Journal 53: 462-466.

Suleimenova, N., Makhamedova, B., Orynbasarova, G., Kalykov, D., Yertayeva, Z., 2019. Impact of resource conserving technologies (RCT) on soil physical properties and rapeseed (Brassica napus L.) yield in irrigated agriculture areas of the south-eastern Kazakhstan. Eurasian Journal of Soil Science 8(1): 83-93.

Wang, J., Liu, W.Z., Mu, H.F., Dang, T.H., 2010. Inorganic phosphorus fractions and phosphorus availability in a calcareous soil receiving 21-year superphosphate application. Pedosphere 20(3): 304-310.

Williams, E.G., Scott, N.M., McDonalds, M.J., 1958. Soil properties and phosphate sorption. Journal ofthe Science of Food and Agriculture 9: 551-559.

Yang, J.E., Jacobsen, J.S., 1990.Soil inorganic phosphorus fractions and their uptake relationships in calcareous soils. Soil Science Society of America Journal 54(6): 1666-1669.

Yertayeva, Z., Kızılkaya, R., Kaldybayev, S., Seitkali N., Abdraimova, N., Zhamangarayeva, A., 2019. Changes in biological soil quality indicators under saline soil condition after amelioration with alfalfa (Medicago sativa L.) cultivation in meadow Solonchak. Eurasian Journal of Soil Science 8(3): 189-195.

Yertayeva, Z., Kaldybaev, S., Beketova, A., 2018. The scientific basis of changes in the composition and properties of meadow saline soil of the foothill plains of the ili alatau during a long postmeliorative period. Ecology, Environment and Conservation 24(2): 715-720.

Yousaf, M., Li, J., Lu, J., Ren, T., Cong, R., Fahad, S., Li, X., 2017. Effects of fertilization on crop production and nutrientsupplying capacity under rice-oilseed rape rotation system. Scientific Reports 7: 1270.

Zhang, M.K., He, Z.L., Calvert, D.V., Stoffella, P.J., Yang, X.E., Li, Y.C., 2003. Phosphorus and heavy metal attachment and release in sandy soil aggregate fractions. Soil Science Society of America Journal 67: 1158-1167. 